\title{
International Journal of Information Science and Management: A Bibliometric Analysis
}

\author{
Thavamani K, Kanniyappan R \\ Regional Medical Library \\ Dr MGR Medical University \\ Guindy, Chennai - 600036 \\ India \\ thavamani.k@tnmgrmu@ac.in \\ Sri Balaji Medical College and Hospital \\ Chrompet \\ Chennai - 600044 \\ rkanni27@gmail.com
}

ABSTRACT: This paper presents a bibliometric techniques were used to analyze the authorship trend in contributions of "International Journal of Information Science and Management" during 2003 - 2014. A total of 218 contributions were examined by growth of contributions by year, authorship patterns by year and issue, author productivity, most prolific contributors. Maximum number of contributions i.e., 31 (14.220\%) were published in the year 2010. Average number of authors per paper is $2.133 \%$ and the average productivity per author is $0468 \%$. The highest number of contributors i.e., 367 (78.924\%) are from Iran.

Keywords: Bibliometric, Authorship Patterns, Journal Study, IJISM, Author Productivity

Received: 24 February 2019, Revised 14 April 2019, Accepted 1 May 2019

DOI: $10.6025 /$ jism/2019/9/3/100-107

(C) 2019 DLINE. All Rights Reserved

\section{Introduction}

Bibliometrics is a set of methods to quantitatively analyze academic literature. Citation analysis and content analysis are commonly used bibliometric methods. Although bibliometric methods are most often used in the field of library and information science, bibliometrics contain broad applications in other areas. Many research fields use bibliometric methods to explore the impact of their field, the impact of a set of researchers, or the impact of a particular paper.

\section{International Journal of Information Science and Management (IJISM)}

The International Journal of Information Science and Management (IJISM) is a peer-reviewed open access e-journal. This journal was launched in 2003; it publishes research articles in biannually (July and December) by the Regional Information Centre for Science \& Technology (RICeST) from Shiraz, Iran. It is a scholarly journal in English devoted to the various fields of Library and

\begin{tabular}{lllll}
\hline 100 & Journal of Information \& Systems Management Volume 9 Number 3 September 2019 \\
\hline
\end{tabular}


Information Science. The journal publishes original research articles in the fields of Scientrometrics, Webometrics, Library and information science, Information Management, Informatics and Information Technology. This journal provides immediate open access to its content on the principle that making research freely available to the public supports a greater global exchange of knowledge. This journal was published before 2007 (volume 5 issue 1) in the name of Iranian journal of Information Science and Technology. It is approved by the Ministry of Science, Science and Technology as a Scientific - Research Journals Iran. The journal is being indexed by ELSEVIER, EBSCO, SCOPUS, ISC and Iran Journal (RICeST).

\section{Objectives of the Study}

The primary objective of this study is to understand the growth of International Journal of Information Science Management and contributor's research outputs in global during the period 2003 - 2014. More specific objectives are as follows;

1. To study growth of articles by year and issues,

2. To study authorship patterns by year and volume,

3. To study authorship patterns,

4. To study author's productivity,

5. To trace contributions by department,

6. To trace authorship patterns by country,

7. To identify authors affiliation,

8. To identify most prolific contributors and

\section{Methodology and Data Collection}

The data was collected from "International Journal of Information Science and Management (IJISM)" journal website (www.ricest.ac.ir) covering the period from 2003 - 2014. Twenty eight issues of twelve volumes (Vol.1 - 12) have been selected for the study. For each article, growth of articles by year and issues, authorship patterns by year and volume, authorship patterns, author productivity, contributions by department, average length of articles, single and multi authored papers by year, authorship patterns by country, identify authors affiliation, most prolific contributors were noted down for the study. These data were organized, calculated, tabulated, analyzed and presented by using simple arithmetic and statistical methods in order to arrive for its results. The study limited to 218 research articles published in last twelve years data were noted down for the study.

\section{Analysis and Findings}

The bibliographic records were collected from the online version International Journal of Information Science and Management (IJISM) pertaining to the period 2003-2014. A total of 218 research article records were collected, which formed the source data for this study.

Table 1 shows the growth of publications by year issue during 2003-2014 a total of 218 publications were published by researchers in various countries. The highest number of publications $31(14.220 \%)$ were published in 2010. And the lowest number of i.e 12(5504\%) the total article was published in 2005.

Table 2 shows the authorship patterns by year and volume. Out of the 60 contributions by single author, volume 17 has the highest number (i.e., $8(10.959 \%)$. Volumes 4 and 6 have the lowest number (i.e. $1(1.370 \%)$ contributions. Out of the 38 contributions by two authors, 16 and 17 has the highest (i.e. 6 (15.789\%). And 9 have the lowest number (i.e., 1 (2.632\%) contributions. Out of 12 contributions by three authors, 18 has the highest (i.e. 4 (33.333\%) and 15 has the lowest number (i.e., $1(8.333 \%)$ contributions.

Majority of the papers have been written in two authored which shows in the table 3. It is seen that the highest i.e., $94(43.119 \%)$ of publications are two authored and $60(27.112 \%)$ are single authored papers. And $41(18.807 \%)$ contributions are contributed by three authors and the lowest number of contributions i.e., $2(0.917 \%)$ contributed by five authors.

Journal of Information \& Systems Management Volume 9 Number 3 September 2019 


\begin{tabular}{|c|c|c|c|c|c|c|}
\hline S. No. & Year & Volume Number & Issue Number & $\begin{array}{c}\text { Total Number of } \\
\text { Contributors }\end{array}$ & Total & Percentage $\%$ \\
\hline \multirow[t]{2}{*}{1} & \multirow[t]{2}{*}{2003} & \multirow[t]{2}{*}{1} & 1 & 7 & \multirow{2}{*}{14} & \multirow{2}{*}{6.422} \\
\hline & & & 2 & 7 & & \\
\hline \multirow[t]{2}{*}{2} & \multirow[t]{2}{*}{2004} & \multirow[t]{2}{*}{2} & 1 & 7 & \multirow{2}{*}{14} & \multirow{2}{*}{6.422} \\
\hline & & & 2 & 7 & & \\
\hline \multirow[t]{2}{*}{3} & \multirow[t]{2}{*}{2005} & \multirow[t]{2}{*}{3} & 1 & 6 & \multirow[t]{2}{*}{12} & \multirow[t]{2}{*}{5.504} \\
\hline & & & 2 & 6 & & \\
\hline \multirow[t]{2}{*}{4} & \multirow[t]{2}{*}{2006} & \multirow[t]{2}{*}{4} & 1 & 7 & \multirow[t]{2}{*}{14} & \multirow[t]{2}{*}{6.422} \\
\hline & & & 2 & 7 & & \\
\hline \multirow[t]{2}{*}{5} & \multirow[t]{2}{*}{2007} & \multirow[t]{2}{*}{5} & 1 & 8 & \multirow[t]{2}{*}{17} & \multirow[t]{2}{*}{7.798} \\
\hline & & & 2 & 9 & & \\
\hline \multirow[t]{2}{*}{6} & \multirow[t]{2}{*}{2008} & \multirow[t]{2}{*}{6} & 1 & 8 & \multirow[t]{2}{*}{15} & \multirow[t]{2}{*}{6.880} \\
\hline & & & 2 & 7 & & \\
\hline \multirow[t]{2}{*}{7} & 2009 & 7 & 1 & 8 & 15 & 6.880 \\
\hline & & & 2 & 7 & & \\
\hline 8 & 2010 & 8 & 1 & 7 & 31 & 14.220 \\
\hline & & & 2 & 8 & & \\
\hline & & Special issue & 1 & 8 & & \\
\hline & & Special issue & 11 & 8 & & \\
\hline 9 & 2011 & 9 & 1 & 7 & 15 & 6.880 \\
\hline & & & 2 & 8 & & \\
\hline 10 & 2012 & 10 & 1 & 7 & 26 & 11.926 \\
\hline & & & 2 & 10 & & \\
\hline & & Special issue & $\mathbf{I}$ & 9 & & \\
\hline 11 & 2013 & 11 & 1 & 7 & 23 & 10.550 \\
\hline & & & 2 & 7 & & \\
\hline 12 & 2014 & 12 & 1 & 7 & & \\
\hline & & Special issue & Kish Conference & 8 & 22 & 10.091 \\
\hline & & & 2 & 7 & & \\
\hline & & 28 Issues & 28 & 218 & 218 & 100.00 \\
\hline
\end{tabular}

Table 1. Contributions by Year/volume and Issue

\begin{tabular}{|c|c|c|c|c|c|l|l|l|l|}
\hline \multirow{2}{*}{ No. } & Year & Volume & \multicolumn{4}{|l|}{ Authors } & \multirow{2}{*}{ Total } & \multirow{2}{*}{ Percentage } \\
\cline { 4 - 8 } & & & Single & Two & Three & Four & Five & & \\
\hline 1 & 2003 & 1 & 7 & 6 & & 1 & & 14 & 6.422 \\
\hline
\end{tabular}




\begin{tabular}{|l|l|l|l|l|l|l|l|l|l|}
\hline 2 & 2004 & 2 & 6 & 6 & 2 & & & 14 & 6.422 \\
\hline 3 & 2005 & 3 & 4 & 6 & 2 & & & 12 & 5.504 \\
\hline 4 & 2006 & 4 & 4 & 6 & & 4 & & 14 & 6.422 \\
\hline 5 & 2007 & 5 & 7 & 8 & 1 & 1 & & 17 & 7.798 \\
\hline 6 & 2008 & 6 & 6 & 6 & 2 & & 1 & 15 & 6.880 \\
\hline 7 & 2009 & 7 & 5 & 7 & 3 & & & 15 & 6.880 \\
\hline 8 & 2010 & 8 & 4 & 18 & 8 & 1 & & 31 & 14.220 \\
\hline 9 & 2011 & 9 & 4 & 7 & 1 & 3 & & 15 & 6.880 \\
\hline 10 & 2012 & 10 & 6 & 10 & 6 & 4 & & 26 & 11.926 \\
\hline 11 & 2013 & 11 & 2 & 6 & 9 & 5 & 1 & 23 & 10.550 \\
\hline 12 & 2014 & 12 & 5 & 8 & 7 & 2 & & 22 & 10.091 \\
\hline Total & & $\mathbf{6 0}$ & $\mathbf{9 4}$ & $\mathbf{4 1}$ & $\mathbf{2 1}$ & $\mathbf{2}$ & $\mathbf{2 1 8}$ & $\mathbf{1 0 0 . 0 0}$ \\
\hline
\end{tabular}

Table 2. Authorship patterns by Year/Volume

\begin{tabular}{|l|l|l|l|}
\hline Sl. No. & Author & Total & Percentage (\%) \\
\hline 1 & Single Author & 60 & 27.522 \\
2 & Two Authors & 94 & 43.119 \\
3 & Three Authors & 41 & 18.807 \\
4 & Four Authors & 21 & 9.633 \\
5 & Five Authors & 2 & 0.917 \\
\hline Total & & $\mathbf{2 1 8}$ & $\mathbf{1 0 0 . 0 0}$ \\
\hline
\end{tabular}

Table 3. Authorship Patterns

\begin{tabular}{|l|l|l|c|c|c|}
\hline Sl. No. & Year & Total No. of Papers & Total No. of Authors with \% & AAPP* & Productivity per Author \\
\hline 1 & 2003 & 14 & 23 & 1.642 & 0.608 \\
\hline 2 & 2004 & 14 & 24 & 1.147 & 0.583 \\
\hline 3 & 2005 & 12 & 22 & 1.833 & 0.545 \\
\hline 4 & 2006 & 14 & 32 & 2.285 & 0.437 \\
\hline 5 & 2007 & 17 & 30 & 1.764 & 0.566 \\
\hline 6 & 2008 & 15 & 29 & 1.933 & 0.517 \\
\hline
\end{tabular}




\begin{tabular}{|c|l|l|c|c|c|}
\hline 7 & 2009 & 15 & 28 & 1.866 & 0.535 \\
\hline 8 & 2010 & 31 & 68 & 2.774 & 0.455 \\
\hline 9 & 2011 & 15 & 33 & 2.2 & 0.454 \\
\hline 10 & 2012 & 26 & 60 & 2.307 & 0.433 \\
\hline 11 & 2013 & 23 & 66 & 2.869 & 0.348 \\
\hline 12 & 2014 & 22 & 50 & 2.272 & 0.44 \\
\hline Total & & $\mathbf{2 1 8}$ & $\mathbf{4 6 5}$ & $\mathbf{2 . 1 3 3}$ & $\mathbf{0 . 4 6 8}$ \\
\hline
\end{tabular}

Table 4. Author's Productivity

*Average Authors per Paper (AAPP) $=$ Number of authors/ Number of papers.

\begin{tabular}{|l|l|l|l|l|}
\hline SI. & No. Name & $\begin{array}{l}\text { Numberof } \\
\text { Contributions }\end{array}$ & Country & Rank \\
\hline 1 & Mehrad.J & 14 & Iran & 1 \\
\hline 2 & Sanayei. A & 11 & Iran & 2 \\
\hline 3 & Alijani. R & 4 & Iran & 3 \\
\hline 4 & Ansari. A & 4 & Iran & 3 \\
\hline 5 & Farideh Osareh & 4 & Iran & 3 \\
\hline 6 & Fattahi.R & 4 & Iran & 3 \\
\hline 7 & Jamshidian. M & 4 & Iran & 3 \\
\hline 8 & Rezaei Sharifabadi S & 4 & Iran & 3 \\
\hline 9 & Shabani.A & 4 & Iran & 3 \\
\hline 10 & Didegah. F & 3 & U.K & 4 \\
\hline 11 & Erfanmanesh. M.A & 3 & Malaysia & 4 \\
\hline 12 & Faghih. N & 3 & Iran & 4 \\
\hline 13 & Hajli.M & 3 & U.K Iran & 4 \\
\hline 14 & Hayati Z & 3 & Iran & 4 \\
\hline 15 & Jahankhani.H & 3 & U.K & 4 \\
\hline 16 & Osareh. F & 3 & Iran & 4 \\
\hline 17 & Two Author Contributions & 34 & - & 5 \\
\hline 18 & Single Author Contributions & 323 & -- & 6 \\
\hline Total & & 465 & -- & - \\
\hline
\end{tabular}

Table 5. Most Prolific Contributors 


\begin{tabular}{|l|l|c|l|}
\hline $\begin{array}{l}\text { Sl. } \\
\text { No. }\end{array}$ & Institutions & Total & Percentage (\%) \\
\hline 1 & Academic Institutions & 398 & 85.591 \\
\hline 2 & Research Institutions & 19 & 4.086 \\
\hline 3 & Special Institutions & 18 & 3.870 \\
\hline 4 & Government Institutions & 23 & 4.946 \\
\hline 5 & Institutions not mentioned & 7 & 1.505 \\
\hline & Total & 465 & 100.00 \\
\hline
\end{tabular}

Table 6. Contributions by Institutions

\begin{tabular}{|l|l|l|c|}
\hline Sl. No. & Name of the Department & Total & Percentage (\%) \\
\hline 1 & Department of Library and Information Science & 35 & 13.207 \\
\hline 2 & Department of Computer Engineering & 26 & 9.811 \\
\hline 3 & Department of Electrical Engineering & 18 & 6.792 \\
\hline 4 & Department of Management & 14 & 5.283 \\
\hline 5 & Department of Information Sciences & 8 & 3.018 \\
\hline 6 & Department of Management and Accounting & 7 & 2.641 \\
\hline 7 & Department of Information Technology & 7 & 2.641 \\
\hline 8 & Department of Administrative Sciences \& Economics & 7 & 2.641 \\
\hline 9 & Department of Engineering & 5 & 1.886 \\
\hline 10 & Department of Medical Library \& Information Sciences & 5 & 1.886 \\
\hline 11 & Department of Marketing Management & 3 & 1.132 \\
\hline 12 & Department of Health Management and Information Sciences & 3 & 1.132 \\
\hline 13 & Department of Economics and Social Sciences & 3 & 1.132 \\
\hline 14 & Department of Business Management & 3 & 1.132 \\
\hline 15 & Department of Business Administration Management & 3 & 1.132 \\
\hline 16 & Department of Agricultural Machinery & 3 & 1.132 \\
\hline 17 & Two Department contributions & 33 & 269.811 \\
\hline 18 & One Department contribution & $\mathbf{2 6 5}$ & $\mathbf{1 0 0 . 0 0 0}$ \\
\hline 19 & Department not mentioned & 3613.584 \\
\hline & Total & 20.000 \\
\hline
\end{tabular}

Table 7. Contributions by Department 


\begin{tabular}{|l|l|c|l||c|l|c|l|}
\hline Sl. No. & Country & $\begin{array}{l}\text { Number of } \\
\text { Contributions }\end{array}$ & $\begin{array}{l}\text { Percentage } \\
(\%)\end{array}$ & Sl. No. & Country & $\begin{array}{l}\text { Number of } \\
\text { Contributions }\end{array}$ & $\begin{array}{l}\text { Percentage } \\
(\%)\end{array}$ \\
\hline 1 & Iran & 367 & 78.924 & 13 & Rabat Morocco & 3 & 0.645 \\
\hline 2 & Malaysia & 18 & 3.87 & 14 & Jordan & 2 & 0.43 \\
\hline 3 & U.K & 16 & 3.44 & 15 & China & 2 & 0.43 \\
\hline 4 & India & 9 & 1.935 & 16 & Azerbaijan & 2 & 0.43 \\
\hline 5 & Germany & 6 & 1.29 & 17 & Australia & 2 & 0.43 \\
\hline 6 & France & 5 & 1.075 & 18 & Sweden & 1 & 0.215 \\
\hline 7 & Bangladesh & 5 & 1.075 & 19 & Sri Lanka & 1 & 0.215 \\
\hline 8 & USA & 4 & 0.86 & 20 & Dubai, UAE & 1 & 0.215 \\
\hline 9 & Nigeria & 4 & 0.86 & 21 & Canada & 1 & 0.215 \\
\hline 10 & Yemen & 3 & 0.645 & 22 & Botswana & 1 & 0.215 \\
\hline 11 & Taiwan & 3 & 0.645 & 23 & No Place & 6 & 1.29 \\
\hline 12 & $\begin{array}{l}\text { Sultanate } \\
\text { of Oman }\end{array}$ & 3 & 0.645 & & & & \\
\hline
\end{tabular}

Table 8. Authorship patterns by Country

Table-4 gives the data related to author's productivity of contributions, which shows that the total average number of authors per paper is 2.133 and the average productivity per author is 0.468 . The highest number of authors productivity i.e., $68(0.455 \%)$ were published in the year 2010. The minimum number of authors productivity i.e., $12(0.545 \%)$ in the year 2005 . A total of 465 authors contributed 218 papers over a period of eighteen years $(2003-2014)$ which shows in table 5. The most prolific contributor Mehrad.J (Iran) stood in the first position; he contributed the highest number (14) of publications. This is followed by Sanayei. A (Iran) is stood in second highest contributions with 11 publications. Seven authors contributed 4 papers each. Seven authors contributed 3 papers each. 34 authors contributed two papers each. And 323 publications are contributed by single authored contributions.

Table 6 shows the type of institutions with which the authors of the articles were affiliated. Majority of $398(85.591 \%)$ articles were from academic institutions, followed by Government institutions with $23(4.946 \%)$, research institutions $19(4.086 \%)$, special institutions $18(3.870 \%)$. And 7 (1.505\%) articles are institutions not mentioned.

Table 7 shows the type of departments with which the authors of the articles were affiliated. Majority of $35(13.207 \%)$ articleswere from Department of Library and Information Science, followed by Department of Computer Engineering with 26 (9.811\%). And $53(20.000 \%)$ articles are department not mentioned.

The country wise contributions shows in the above table 8, which shows the total of 23 countries, contributed 218 articles contributed by 465 authors. The highest number of contributors i.e., 367 (78.924\%) are from Iran. The second highest contributions are from Malaya i.e., 18 (3.870\%). This is followed U.K by 16 (3.440\%) contributions; India by 9 (1.935\%) contributions;

\begin{tabular}{lllllll}
\hline 106 & Journal of Information \& Systems Management Volume 9 & Number 3 & September 2019 \\
\hline
\end{tabular}


Germany by $6(1.290 \%)$ contributions. The lowest number of contributions $1(0.215 \%)$ were from Sweden, Sri Lanka, Morocco, Dubai, Canada and Botswana respectively

\section{Conclusion}

The bibliometrics study of International journal of Information Science and Management; their authorship trend and the degree of collaboration was steady growth of research output in the journal is observed. The highest number of publications 31 $(14.220 \%)$ were published in 2010. Majority i.e., 94 (43.119\%) of are two authored publications. Average number of authors per paper is 2.133 and the average productivity per author is 0.468 . The highest number of authors productivity i.e., $68(0.455 \%)$ were published in the year 2010. Majority of 398 (85.591\%) articles were from academic institutions, followed by Government institutions with 23 (4.946\%). Majority of 35 (13.207\%) articles were from Department of Library and Information Science, followed by Department of Computer Engineering with 26 (9.811\%). The maximum number of contributors i.e., 367 (78.924\%) are from Iran. The second highest contributions are from Malaysia i.e., 18 (3.870\%). As of today, there are 23 countries contributing research articles to the journal. The study concludes that multi-authorship research is leading as compare to single authored contributions in case of International journal of Information Science and Management.

\section{References}

[1] Alimi, M, Taslimi, Sh,, Ghodsi, M., \& Rahimi-Movaghar, V. (2013). Quality and quantity of research publications by Iranian research publications by Iranian neurosurgeons: Signs of scientific progress over the past decades, Surgical Neurological International, 4 (38).

[2] Amsaveni, N., Vasanthi, R. (2013). Authorship Pattern and Collaborative Research in the Field of Network Security, Indian Journal of Applied Research, 3 (1) 52-54.

[3] Gurjeet Kaur Rattan. (2014) Pakistan Journal of Library and Information Science: A Citation Analysis, Asian Journal of Multidisciplinary Studies, 2 (2) 35-41.

[4] Hussain, Akhta., Fatima, Nishat. (2011) A bibliometric analysis of the 'Chinese Librarianship: an International Electronic Journal, (2006-2010). Chinese Librarianship: an International Electronic Journal, 31. URL: http://www.iclc.us/cliej/cl31HF.pdf.

[5] Jena, Kamal Lochan. (2006). A bibliometric analysis of the journal 'Indian Journal of Fibre and Textile Research, 1996-2004' Annals of Library and Information Studies. 53 (1) 22-30.

[6] Mousavi, S., Mansouri, A., Ahmadvand, A. (2013). A bibliometric study of publication patterns in rational use of medicines in Iran, Pharmacy Practice, 11 (1) 38-43. 